\title{
DOES RELIGIOSITY AFFECT THE INTENTION TO PURCHASE HALAL FAST FOOD FROM NON-MUSLIM COUNTRIES OF ORIGIN?
}

\author{
Arie Indra Gunawan ${ }^{a}$ \\ Vanessa Gaffar ${ }^{\text {b }}$ \\ ${ }^{a}$ Marketing Management Program, Bussiness Administration Department, Politeknik Negeri \\ Bandung \\ ${ }^{\mathrm{b}}$ Management Department, Faculty of Economics and Business Education, Universitas \\ Pendidikan Indonesia \\ Email: arie.indra@polban.ac.id ${ }^{a} ; \underline{v a n e s s a @ u p i . e d u ~}^{b}$
}

ARTICLE HISTORY
Received:
13 January 2021
Revised
4 April 2021
Accepted:
31 May 2021
Online available:
30 June 2021
Keywords:
Halal Fast Food,
Religiosity,
Country of Origin,
Intention to Halal Food,
Purchase Intention.
*Correspondence:
Name:
Arie Indra Gunawan
E-mail:
arie.indra@polban.ac.id

ARTICLE HISTORY

13 January 2021

Revised

4 April 2021

Accepted:

31 May 2021

Online available: arie.indra@polban.ac.id

\begin{abstract}
This paper aims to increase knowledge about the buying intention of halal fast food products. This study examines the influence of the country of origin of halal fast-food providers on purchase intentions. This study also measures the role of religiosity in mediating the relationship between country of origin and purchase intention of halal fast food. This knowledge will be very meaningful because the condition of Indonesia is the largest halal ecosystem, but in the fastfood category, it is dominated by providers from non-Muslim foreign countries. This research is a descriptive study, questionnaires were distributed randomly online via social media, finally getting 245 data from millennial Muslim consumers who could become research respondents. SEM-PLS with the help of statistical software WarpPLS 7.0 is used to explain the research model. This study shows that country of origin affects the purchase intention of halal fast food products, besides this research shows that religiosity is able to moderate country of origin towards the purchase intention of halal fast food. The results of this study reinforce the assumption that country of origin has a significant effect on purchase intention. Especially in fast food products, millennial consumers in Indonesia show that they already have a point of view and perception about the country of origin of halal fast food in Indonesia. Another finding in the study is that religiosity influences the purchase intention of halal fast-food, and has a moderating effect on the country of origin on purchase intention.
\end{abstract}

\section{INTRODUCTION}

Halal food products are growing quite rapidly in all parts of the world. In a special context, there are reasons why halal food is growing rapidly (Suhartanto et al., 2019). Halal food is believed to be healthier and more hygienic because through the correct process according to the rules, the handling procedures are carried out as well as possible so that food can be consumed without any doubts. Therefore, halal food can easily be accepted by the entire population, both Muslim and non-Muslim, because through the goodness contained in halal food, everyone needs halal food 
and there is no prohibition to consume it even from a non-Muslim point of view. In developing countries with a large population and high Muslim domination, the need for halal food is of great concern. Halal food is one of the provisions that must be fulfilled by the food industry, the inclusion of halal labels and information is one of the determinants of whether a product is purchased or not (Wibowo \& Madusari, 2018). This high demand for halal food requires a variety of food categories, from staple foods to substitute foods. Fast food is a variety of foods that consumers often buy in Indonesia. Based on the data obtained, Indonesia is one of the countries where the level of variation in the consumption of halal food is quite high (Fauzia, 2018). Halal fast food is one category of the food industry that is currently growing rapidly which correlates with the increasing consumer demand. The number of halal fast food providers in Indonesia continues to grow, ranging from local SME entrepreneurs to large-scale fast-food providers from foreign countries. These conditions make the halal fast food industry a fast-growing and very competitive industry.

The development of the fast-food industry has received a good response from consumers, especially the millennial generation who have high activity and involvement with food. They have their own intentions in their attitude towards fast food, they consider fast food to be a common thing and an alternative food that can be obtained quickly, easily, and is delicious to eat. Several previous studies have been carried out on halal fast food products, the results of research show that halal fast food products are in demand by consumers, the majority of consumers claim to have an interest and will buy halal fast food (Nusaresearch, 2014). The key to the success of being interested in halal fast food products by the market is that they make strategic adjustments and also target consumer behavior by involving habits, lifestyles, and actual legal issues in promoting them (Mariana et al., 2020). The millennial generation is considered to have a high level of involvement with actual issues which will then be converted into their lifestyle and habits (Amalia et al., 2020), so indirectly the actual issues surrounding halal and fast food greatly contribute to the growth of the halal lifestyle among young people. The high intention in purchasing halal fast-food in Indonesia is an attraction for companies to try to expand the Indonesian market, because Indonesia is the largest halal ecosystem with a large population, and a high majority of Muslims (Mastuki, 2019). Many fast food companies come from overseas (Country Of Origin) such as America, Europe, and Australia, trying to reach the Indonesian market and making some adjustments to Indonesian culture, one of which is targeting halal certification. With the current conditions, halal products are not only the center of attention of Islamic countries but also "secular" or Muslim minority countries because halal products have become part of the world's business with a very large and promising value. As

Published by University of Airlangga.

This is an open access article under the CC BY license (https://creativecommons.org/licenses/by-nc-sa/4.0/) 
stated by Mastuki (2020), halal products are not only for the Muslim community but also non-Muslims

Indonesian halal fast food providers are dominated by countries that have different cultures from Muslims habit, they are come from non-Muslim countries and their food handling process adjustments are made so that their products meet the requirements according to Islamic law and are worthy of obtaining Halal certification. When viewed from their culture, non-Muslim countries have customs and cultures that are contrary to Islamic teachings. Of course, this is an interesting condition to be used as study material as Indonesia is the largest halal ecosystem, but their halal fast food providers are dominated by countries or companies with a background of nonMuslims. Consumers will have a high intention in buying halal food if a food is clearly halal. Therefore, a Muslim can consume the food without worrying about anything else (Awan et al., 2015). In the conditions that occur, it is possible that a "conflict of interest" will occur because the provider of the halal product has an image of the product and a country of origin which is not a Muslim country. So, for Indonesian Muslim consumers, this is used as an evaluation material.

Based on the industrial conditions that occur, it can be seen that the gap in the form of intention to purchase fast-food in Muslim-majority countries is very high, while fast food providers are countries that are non-Muslim, fast food providers that come from non-Muslim countries of origin can raise doubts for Muslim consumers. Based on this gap, this study was conducted to determine whether the intention of buying fast food in the millennial Muslim consumer market is influenced by the aspects of the country of origin and the level of religiosity. This study examines the country of origin and religious aspects as exogenous variables of the intention to purchase halal products, where these two variables are the results of a literature study and the actual conditions that occur in the halal fast-food industry.

This research is different from that conducted in Amalia et al. (2020) and Mariana et al. (2020), which measures the intention to purchase halal products using the theory plan of behavior application. In research conducted, the variable country of origin is measured by six indicators, namely reliable, quality, reputation, value, looks better, and more like. Meanwhile, religious variables are also constructed by six indicators, namely the importance of religious faith, spend time to understanding my faith, the influence of religious beliefs, the importance of religious, spend time to remember Allah SWT, and relationship with Allah SWT. This research is expected to provide new insights regarding the academic concept of halal fast-food, especially those carried out by non-Muslim countries that have Muslim consumer market segments. In addition, this study is also expected to provide an overview of managerial implications for the fast food industry regarding the strategies being undertaken in reaching Muslim consumers. 


\section{LITERATURE REVIEW}

Modern marketing is characterized by a change from a consumer-centric to a value-driven approach. A strong market orientation, target group market research and the integration of consumers in the product development process are identified as key factors for the success of innovation in the food industry. The food and beverage industry is very well developed. This happens because of several open innovations, shortening the product life cycle, digitization, adjusting to changing tastes and consumer needs, and other relevant factors. These conditions make the innovation process develop more rapidly (Bresciani, 2017). One application-driven approach is to consider the aspirations, values, and beliefs of a population group, such as halal law (anything that is allowed) which is based on Islamic values beverage industry in carrying out its production (Hassan, 2014). The presentation of halal labeling is used as a basis for processing and implementing products as a priority in the culinary business (Pusparini \& Setiaji, 2019).

Fast food is a food industry that adapts its value-driven very quickly by doing the halal certification. In Indonesia, halal fast food providers on a large scale are dominated by foreign countries with a majority non-Muslim background. Of course, this can be one of the considerations for Muslim consumers in their interest in consuming halal fast food, in these condition consumers are expected to be more selective. The image of a product can be formed based on where the product comes from. There are two main concepts about country of origin which is related to the product stereotype that consumers attach to. The first concept is the image of the country at the product level, where this image is the general perception of consumers on the quality of products from a particular country. The second concept is the country's image of the country, namely consumer perceptions of a particular country.

The results of previous research indicate that the country of origin has a significant effect on consumption interest (Hsu et al., 2017). This study examines customer confidence in certain countries in consuming halal products as measured using the context of reliability, the ability to provide better quality has a good reputation, has more value, looks better liked by consumers (Hsu et al., 2017). In conclusion, the country of origin has an impact on customer purchase intentions (Nasution \& Rossanty, 2018).

\section{H1: Country of origin has a significant effect on purchase intention in halal fast food}

Religiosity is inherent in every Muslim because it is basically a person's belief in his religion, believing in something he thinks is true so that it becomes a principle in his life (Hasan \& Marso, 2017). Someone who has the value of religiosity will take 
the time to understand religion and maintain a relationship with God by instilling religious values in their daily life by doing what is ordered and staying away from what is prohibited by religion, this is a personal commitment owned by someone who have a high level of religiosity. The religious factor is very important, especially if it is related to aspects of consumer behavior, the level of religiosity is one of the factors that influence behavior and intentions. The halal category is very closely related to Muslim culture, so this level of religiosity will affect consumption patterns, differentiating halal food from haram food has become the main need of Muslims (Sushanti et al., 2019). Several studies have shown that a person's level of religiosity can influence a person's decision to consume because a person's level of belief in something religious in nature can affect one's behavior. Thus, this religious factor will be able to influence consumer behavior, including in the intention and decision making to choose food that will be consumed (Suhartanto et al., 2018).

\section{H2: Religiosity has a significant effect on halal fast food purchase intention}

There are guidelines on food for Muslims described in the Al-Quran, these guidelines refer to binding rules, namely that the food eaten must have halal and tayyib (good) elements (Ali, 2016; Ashraf \& Rahman, 2018). Food consumption for Muslims is very clearly regulated. This is an obligation that must be fulfilled, because the selection of halal and tayyib food is not only for the fulfillment of religious values but also for the aspects of goodness for those who consume it (Amalia et al., 2020). A person who has a high level of religiosity will behave in accordance with the guidance of his religion, including in choosing food for consumption. For a Muslim, halal is a part of religiosity that is integrated in his daily life (Borzooei \& Asgari, 2015).

Indonesia is the largest halal consumer market because it has a very large number of Muslims, even the largest in the world (Mastuki, 2019). This growing market is the concern of business people because it is considered to have great potential, based on the results of a survey of Indonesian people's interest in halal fast food, which continues to increase (Nusaresearch, 2014). Halal fast-food providers are dominated by non-Muslim countries. They have obtained a halal certification permit, so they have the understanding and awareness to ensure the halal of the products they distribute (Ali, 2016). Behind the halal certification that is owned, this halal fastfood provider clearly has the image of a non-Muslim country. Hence, it is possible to have a cognitive aspect that connects the image association of non-Muslims in forming halal fast-food purchase intentions, because someone who has a level of religiosity will always trying to avoid things that is doubtful.

H3: The role of religiosity moderates the relationship between Country of Origin and purchase intention on halal fast food 


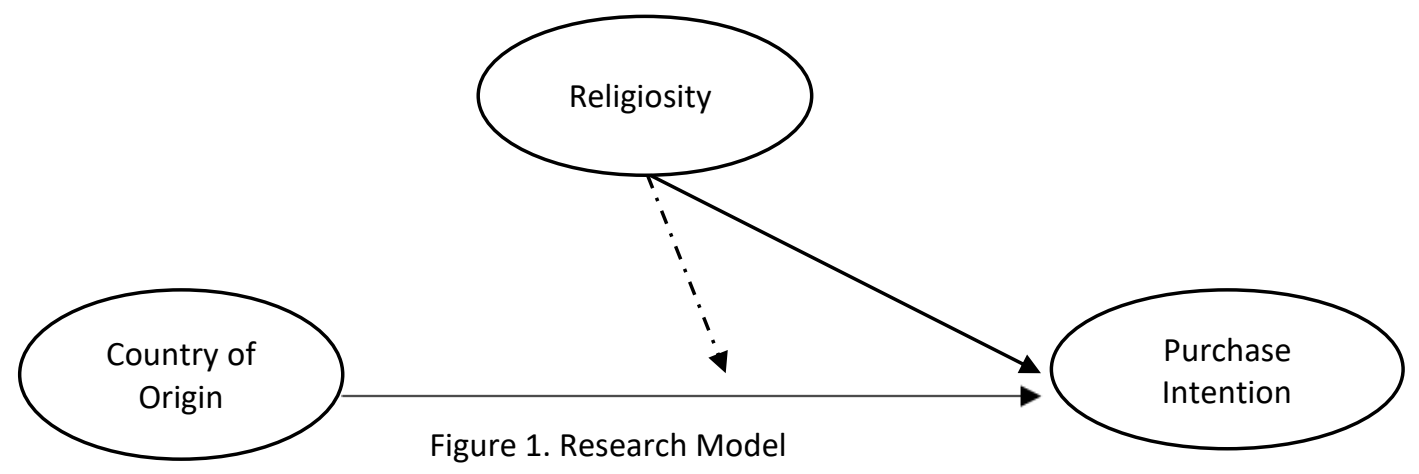

\section{RESEARCH METHODS}

The quantitative approach was applied in this study because the research process, measurement, hypothesis testing and data analysis used numerical data. While the research design to be carried out in this study is included in descriptive form, where the hypothesis has been formulated at the beginning of the study (Malhotra \& Birks, 2017). The subjects of this study were generation Y Muslim consumers with an age range between 20-35 years (Berkup, 2014). This was done because they were considered to be more sensitive in terms of choosing halal food (Amalia et al., 2020). Questionnaires were distributed online via social media for several weeks, obtained 245 respondents data can be analyzed further.

Sources of data in this study consisted of primary data and secondary data. Primary data is obtained through sources that are collected directly so that the research objectives can be achieved, meanwhile secondary data is collected as supporting data and references used by researchers based on previous research. The research instrument uses a Likert scale (1-5) to measure a variable. Research modeling using Structural Equation Modeling-Partial Least Square (SEM-PLS) is applied to minimize the risk of errors in variable measurement due to perceptual construct-based assessment (Kock, 2019). WarpPLS 7.0 was chosen to analyze SEMPLS because it makes it very easy to carry out the analysis of interpretation, and the input data can come from all types of scales. Besides, it can perform complex structural model tests, the results of path analysis can be done in one regression analysis.

Convergent validity test and discriminant are being used in this research. Convergent validity test shows the score contained in the factor loadings while the discriminant validity test is using Average Variance Extracted (AVE). Outer loading must have a score of 0.4 or more, while for AVE it must have a score of 0.5 or more. Inner model testing is a structural test that includes Goodness of Fit (GoF), Path Coefficient, R-Square, and Effect Size. This test is carried out to test the relationship 
between exogenous and endogenous constructs that have been hypothesized (Hair, Hult, Ringle, \& Sarstedt, 2016)

\section{RESULT AND ANALYSIS}

From the results of data collection, the researcher then conducted an analysis of 245 respondents as shown in Table 1.

Table 1

Respondent Demographic

\begin{tabular}{llcc}
\hline & Description & Frequency & Percentage (\%) \\
\hline \multirow{3}{*}{ Gender } & Female & 147 & 60 \\
& Male & 98 & 40 \\
\multirow{3}{*}{ Profession } & Student & 109 & 44.5 \\
& Employee & 95 & 38.8 \\
& Entrepreneur & 10 & 4.1 \\
& Others & 31 & 12.6 \\
\multirow{3}{*}{ Education } & High School & 7 & 2.9 \\
& High School & 116 & 47.3 \\
& Bachelor & 117 & 47.8 \\
& Post Graduate & 5 & 2 \\
\hline
\end{tabular}

Source: WarpPLS 7.0 Output (Data Processed)

The research respondents based on gender were $60 \%$ women and $40 \%$ men. Based on work, 109 respondents or $44.5 \%$ were students. Meanwhile, $47.8 \%$ respondents had a bachelor's degree. Other results can be seen in Table 2, which shows the results of calculating the loading factor as a test of convergent validity on all items have the score above 0.4 . Furthermore, the result of discriminant validity test reaches the requirements because the score of AVE in each variable is 0.630 (PI), $0.620(\mathrm{R})$, and $0.738(\mathrm{COO})$, in which the entire scores are above 0.5 . This shows that all items that make up these variables are valid and usable.

Table 2

Loading Factor of Research Construct

\begin{tabular}{|c|c|c|c|c|}
\hline Construct/item & Loading & $\alpha$ & CR & AVE \\
\hline Purchase Intention (PI) & & 0.800 & 0.871 & 0.630 \\
\hline Willingness to purchase & 0.827 & & & \\
\hline Effort to purchase in the near future & 0.864 & & & \\
\hline Recommending & 0.817 & & & \\
\hline Consider buying & 0.650 & & & \\
\hline Religiosity (R) & & 0.876 & 0.907 & 0.620 \\
\hline The importance of religious faith & 0.749 & & & \\
\hline Spend time to understanding my faith & 0.683 & & & \\
\hline The influence of religious beliefs & 0.807 & & & \\
\hline The importance of religious & 0.850 & & & \\
\hline
\end{tabular}




$\begin{array}{lllll}\text { Spend time to remember Allah SWT } & 0.794 & & & \\ \text { Relationship with Allah SWT } & 0.829 & 0.929 & \mathbf{0 . 9 4 4} & \mathbf{0 . 7 3 8} \\ \text { Country of Origin (COO) } & & & & \\ \text { Reliable } & 0.842 & & & \\ \text { Quality } & 0.882 & & & \\ \text { Reputation } & 0.813 & & \\ \text { Value } & 0.881 & & \\ \text { Looks better } & 0.871 & & \\ \text { More like } & 0.865 & & \end{array}$

Reliability test was conducted to measure the consistency of the instrument when it is used repeatedly. Cronbach Alpha $(\alpha)$ shows the result of reliability test with the requirement of score is more than 0.6 and the Composite Reliability (CR) must be exceeded than 0.7 (Hair et.al, 2016). Table 2 shows that Cronbach Alpha and CR qualify the criteria. This is indicated by the score of Cronbach Alpha 0.800 (PI), 0.876 $(\mathrm{R})$, and $0.929(\mathrm{COO})$. All variables have score $>0.6$, however the score of $C R$ in each variable have score $>0.7$ which indicated by the score $0.871(\mathrm{PI}), 0.907(\mathrm{R})$, and 0.944 (COO). The result of this reliability test is acceptable and can be used in research. Goodness of Fit (GoF) used to validate the overall structural model. The score of GoF represents different category which are 0.36 (high), 0.25 (medium), and 0.10 (low) (Malhotra \& Birks, 2017). Table 3 shows the score of GoF for the research model is 0.370 which represent this score into the high category. It means the model proposed in this study has a good quality.

Table 3

Model Fit and Quality Indices

\begin{tabular}{lll}
\hline & Model Fit Indices & Values \\
\hline Average Path Coefficient (APC) & 0.195 & $\mathrm{P}<0.001$ \\
Average R-square (ARS) & 0.183 & $\mathrm{P}<0.001$ \\
Average adjusted R-squared (AARS) & 0.173 & $\mathrm{P}<0.001$ \\
Average block VIF (AVIF) & 1.029 & Acceptable \\
Average Full Collinearity VIF (AFVIF) & 1.111 & Acceptable \\
Tenenhaus GoF & 0.370 & \\
\hline WarpPLS 7.0 Output (Data Processed) & &
\end{tabular}

Based on Table 3, the probability value ( $p$-value) of APC $<0.001$, the $p$-value of ARS $P<0.001$, and $p$-value of AARS $P<0.001$ are significant because they are less than 0.001 and. The acquisition of AVIF and AFVIF is less than 5 means that the proposed model is fit (Kock \& Lynn, 2012). Based on the score of the R square, purchase intention is influenced by $18.3 \%$ by the country of origin as well as moderating variables for religiosity. Table 3 shows the result of hypothesis testing which is accepted if the score of $p$-value $<0.005$. Each hypothesis is being tested 
through the default inner model analysis algorithm (Kock, 2015). The entire hypothesis is accepted because it has score of p-value less than 0.01 and 0.05 .

Table 4

Path Coefficient

\begin{tabular}{lcccc}
\hline & Hypothesis & $\beta$ & p-value & Result \\
\hline $\mathrm{H} 1$ & COO $\rightarrow$ PI & 0.311 & $<0.001$ & Accepted* \\
$\mathrm{H} 2$ & REG $\rightarrow$ PI & 0.235 & $<0.001$ & Accepted* \\
H3 & REG-COO $\rightarrow$ PI & 0.039 & 0.268 & Accepted** \\
\hline
\end{tabular}

Note: *Significant at $p<0.01, p<0.05 * *$

Source: WarpPLS 7.0 Output (Data Processed)

Each variable of Country of origin and Religiosity has a different effect on purchase intention. It illustrates that the country of origin significantly influences purchase intention $(\beta=0.311$ and $p<0.01)$. Then, religiosity also has a significant effect toward purchase intention $(\beta=0.190$ and $p<0.05)$. As the moderating variable, the religiosity influence significantly on country of origin towards purchase intention $(\beta=0.039$ and $p<0.05)$.

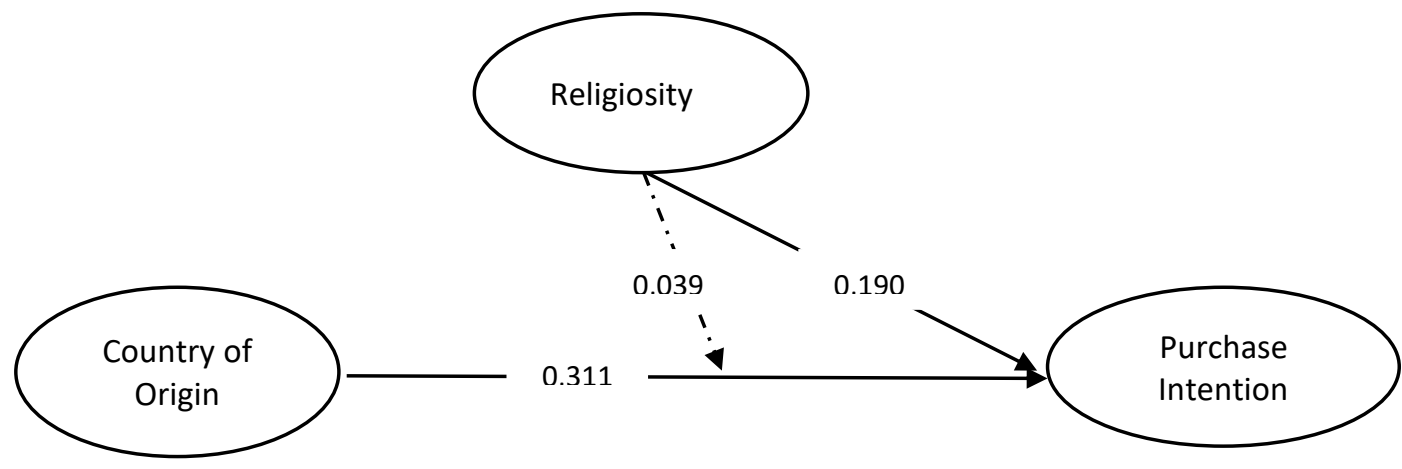

Figure 2. Result from The Model

Based on the description of the research model in Figure 2, the results show that the country of origin of halal fast food affects purchase intention. The results of this study are in line with Hsu et al. (2017) which state that country of origin affects purchase intention. The variables used in this study are different from previous studies, namely involving trustworthiness, having good quality, good reputation, providing added value, looking more handsome, and the level of liking for foreign countries. The concept of this variable has an impact of $31.1 \%$, which when converted into a closeness level is included in the medium category. Based on the research results, it is known that millennial consumers associate various information related to a certain country, so that they can form a general perception about the country of origin which is closely related to the products it produces. 
The religiosity variable has an influence of $19 \%$ on the purchase intention of halal fast-food products. The variables of religiosity in this study include the importance of religious faith which is spend time to understanding my faith, the influence of religious beliefs, the importance of religious, spend time to remember Allah SWT, and relationship with Allah SWT. The influence caused by the religiosity variable indicates that consumers also pay attention to aspects of religious teachings in making purchases, the dominance is only $19 \%$ but it should be noted that this is for purchasing halal products, so that the dominance is felt not too high because millennial Muslim consumers think that halal labeling is sufficient to represent so they believe and do not doubt the halal label that is owned by fast food. The variable of religiosity is considered important by Muslim consumers because religiosity is a guide in Muslim life. This religiosity variable moderates the country of origin variable on purchase intention by $3.9 \%$. Religiosity related to a belief (religion) only affects $19 \%$, and this religious aspect is also a consideration when it comes to the country of origin, but it only affects $3.9 \%$.

The results of this study reinforce the assumption that country of origin has a significant effect on purchase intention. Especially in fast food products, millennial consumers in Indonesia show that they already have a point of view and perception about the country of origin of halal fast food in Indonesia. The majority of halal fastfood providers in Indonesia are foreign countries which are non-Muslim countries, but Indonesian millennial consumers see that the country of origin that is used as their assessment is more towards the condition of a country not based on religion. Indonesian millennial consumers see that the country of origin of these fast-food providers are developed countries that have expected high food quality standards, so they consider that halal fast food with a foreign country of origin is safe for consumption.

Another finding in this study is that religiosity affects purchase intention of halal fast food, and country of origin has a moderating effect on purchase intention. The results of this study are in line with the results of research conducted on previous halal topics, namely that awareness in consuming halal products is determined by a belief in the religion (Nurhayati \& Hendar, 2019). The results show that religiosity can influence Purchase Intention and can be a moderator in buying intention of halal fast food, this shows that the value of religiosity in Indonesia is very influential on purchase intentions of halal products because Indonesia is a market that is predominantly Muslim so it has a high awareness of a halal product.

\section{CONCLUSION}

Based on the research that has been done, it can be concluded that the Country of Origin and Religiosity has a significant effect on consumer purchase intentions. Indonesia, which is a country of halal ecosystems, is due to the majority of 
Muslims, because of this condition Indonesian consumers really pay attention to the country of origin as a provider of consumer products, so this implies that fast food providers originating from non-Muslim foreign countries need to raise a positive image of the country of origin. Another thing that can be done is through positive campaigns and publicity regarding the positive conditions of the country of origin.

In other conditions, providers need to convince Indonesian consumers that even though the country of origin is a non-Muslim foreign country, business ethics and handling processes are carried out with high-quality standards and are subject to strict supervision from both the actors and related stakeholders. Good business ethics will certainly have a positive impact on society. So that consumers will like the product, feel satisfied, happy, and feel that consuming these foods is a good thing.

This study can provide information about consumer behavior in buying halal fast food by using the variable country of origin and Religiosity as moderating variables. However, this study has limitations, there are many other predictor variables that can be used to measure consumer purchase intentions of halal fast food products, especially if it is related to the respondent's subject, there will be variables that might be applied such as the theory of plan of behavior. In addition, this study is only intended for Muslim consumers because it has a specific construct of religiosity for Muslim consumers. Further research can be carried out through a multi-group analysis involving Muslim and non-Muslim consumers. In addition, further research can be conducted to prove whether the findings from this study are the same or have different findings.

\section{ACKNOWLEDGMENT}

This research will not be completed without the involvement of many parties. Therefore, we would like to thank the respondents, and the fast-food industry which is the subject and object of our research. In addition, we also thank our colleagues for the various collaborations that have been carried out, to our institution who gave us the opportunity to carry out one of the marketing researches in the context of halal food. Especially, to the reviewers and the JEBIS editorial team for all meaningful suggestions for our writing. We received a lot of input and were given the opportunity to publish on JEBIS. Thank you very much for JEBIS.

\section{REFERENCES}

Ali, M. (2016). Konsep Makanan Halal dalam Tinjauan Syariah dan Tanggung Jawab Produk Atas Produsen Industri Halal. AHKAM : Jurnal IImu Syariah, 16(2), 291306. https://doi.org/10.15408/ajis.v16i2.4459

Amalia, F. A., Sosianika, A., \& Suhartanto, D. (2020). Indonesian Millennials' Halal food purchasing: merely a habit? British Food Journal, 122(4), 1185-1198. https://doi.org/10.1108/BFJ-10-2019-0748

Awan, H. M., Siddiquei, A. N., \& Haider, Z. (2015). Factors Affecting Halal Purchase Intention - Evidence from Pakistan's Halal Food Sector. Management 
Research Review, 38(2), 640-660. https://doi.org/10.1108/MRR-01-20140022

Berkup, S. B. (2014). Working with generations $X$ and $Y$ In generation $Z$ period: Management of different generations in business life. Mediterranean Journal of Social Sciences, 5(19), 218-229. https://doi.org/10.5901/mjss.2014.v5n19p218

Borzooei, M., \& Asgari, M. (2015). Country-of-Origin Effect on Consumer Purchase Intention of Halal Brands. American Journal of Marketing Research, 1(1), 110. https://www.researchgate.net/publication/273260264

Bresciani, S. (2017). Open, networked and dynamic innovation in the food and beverage industry. British Food Journal, 119(11), 2290-2293. https://doi.org/10.1108/BFJ-08-2017-0458

Fauzia, M. (2018, December). Indonesia Peringkat Pertama untuk Konsumsi Makanan Halal Dunia. Kompas.Com. https://ekonomi.kompas.com/read/2018/12/13/182909026/indonesiaperingkat-pertama-untuk-konsumsi-makanan-halal-dunia

Hair, J.F., Hult, G.T.M., Ringle, C., Sarstedt, M. (2016). A Primer on Partial Least Squares Structural Equation Modeling (PLS-SEM). SAGE Publications Inc.

Hasan, H., \& Marso, M. (2017). Religiosity and Its Consequences in Halal Food Purchasing Behaviour (An empirical Evidence from Tarakan, Indonesia and Tawau, Malaysia). The 8th International Conference of the Asian Academy of Applied Business, December, 0-10.

Hassan, S. H. (2014). The role of Islamic values on green purchase intention. Journal of Islamic Marketing, 5(3), 379-395. https://doi.org/10.1108/JIMA-11-20130080

Hsu, C. L., Chang, C. Y., \& Yansritakul, C. (2017). Exploring purchase intention of green skincare products using the theory of planned behavior: Testing the moderating effects of country of origin and price sensitivity. Journal of Retailing and Consumer Services, 34(October 2016), 145-152. https://doi.org/10.1016/j.jretconser.2016.10.006

Kock, N. (2015). WarpPLS 5.0 User Manual. In ScriptWarp Systems (Issue January). ScriptWarp System.

Kock, N. (2019). Factor-Based Structural Equation Modeling with Warppls. Australasian Marketing Journal, 27(1), 57-63. https://doi.org/10.1016/j.ausmj.2019.02.002

Kock, N., \& Lynn, G. S. (2012). Lateral collinearity and misleading results in variancebased SEM: An illustration and recommendations. Journal of the Association for Information Systems, 13(7), 546-580. https://doi.org/10.17705/1jais.00302

Malhotra, N., \& Birks, D. (2017). Marketing Research: An Applied Approach (5th ed.). Pearson Education Limited.

Mariana, T., Suhartanto, D., \& Gunawan, A. I. (2020). Prediksi Minat Beli Makanan Cepat Saji Halal : Aplikasi Theory of Planned Behavior. The 11th Industrial Research Workshop and National Seminar, 11(1).

Mastuki, H. (2019). Ekosistem Halal: Menjanjikan tapi Menantang. In Kementrian Agama Republik Indonesia. 
https://kemenag.go.id/berita/read/511469.Ekosistem

Mohd Ashraf, A., \& Abd Rahman, F. (2018). Halalan Toyyiban Poultry Feed: an Appraisal from the Maqasid Shariah Perspective. International Journal of Engineering \& Technology, 7(3.21), 306. https://doi.org/10.14419/ijet.v7i3.21.17178

Nasution, M. D. T. P., \& Rossanty, Y. (2018). Country of origin as a moderator of halal label and purchase behavior. Journal of Business and Retail Management Research, 12(2), 194-201. https://doi.org/10.24052/jbrmr/v12is02/cooaamohlapb

Nurhayati, T., \& Hendar, H. (2019). Personal intrinsic religiosity and product knowledge on halal product purchase intention: Role of halal product awareness. Journal of Islamic Marketing, 11(3), 603-620. https://doi.org/10.1108/JIMA-11-2018-0220

Nusaresearch. (2014). Report on Fast Food in Major Cities. February.

Pusparini, M. D., \& Setiaji, H. (2019). Investigating Beyond The Label of "HalalanThayyiban": The Halal Guarantee System in Local Restaurant. International Journal of Islamic Business Ethic (IJIBE), 4(1), 551-562. https://doi.org/10.30659/ijibe.4.1.551-562

Suhartanto, D., Farhani, N. H., Muflih, M., \& Setiawan. (2018). Loyalty intention towards Islamic Bank: The role of religiosity, image, and trust. International Journal of Economics and Management, 12(1), 137-151.

Suhartanto, D., Muflih, M., Najib, M., \& Faturohman, I. (2019). Loyalty Formation towards Halal Food Integrating the Quality-Loyalty Model \& the ReligiosityLoyalty Model. British Food Journal, 122(1), 48-59.

Sushanti, I. R., Idris, M. H., \& Widayanti, B. H. (2019). Local Economic Study on Tourism Development of Halal Case Study: Rinjani Circle Area, Sembalun Sub District, East Lombok District. Ekuilibrium: Jurnal Ilmiah Bidang Ilmu Ekonomi, 14(2), 167. https://doi.org/10.24269/ekuilibrium.v14i2.1932

Wibowo, D. E., \& Madusari, B. D. (2018). Pengaruh Labelisasi Halal Terhadap Keputusan Pembelian Oleh Konsumen Muslim Terhadap Produk Makanan di Kota Pekalongan. Indonesia Journal of Halal, 1(1), 73. https://doi.org/10.14710/halal.v1i1.3400 